\title{
PERAN SENI MUSIK DALAM PENDIDIKAN MULTIKULTURAL
}

\author{
Desyandri \\ Fakultas Ilmu Pendidikan Universitas Negeri Padang \\ desyandri@yahoo.co.id
}

\begin{abstract}
Abstrak
Indonesia merupakan negara yang multikultural, memiliki beragam kebudayaan daerah yang tersebar dari Sabang sampai Merauke, tersebar di beribu-ribu pulau dengan beragam kultur. Tatanan tersebut mengalami perubahan dengan adanya globalisasi dan pengembangan Ilmu pengetahuan, teknologi, dan seni (IPTEKS). Hal ini berdampak pada ketidaksetaraan, dan ketidakadilan dalam dunia pendidikan. Pendidikan secara umum merupakan pemberian pengetahuan, pengalaman dan keterampilan kepada peserta didik sehingga dapat membentuk perilaku positif dan dapat membangun karakter mulia dalam upaya membentuk peradaban bangsa dengan memperhatikan nilai-nilai keragaman budaya. Pendidikan seni musik memberikan pengetahuan, pengalaman, dan kompetensi melalui 5 komponen dasar, yakni: ekspresi, apresiasi, kreasi, harmoni, dan keindahan yang diintegrasikan dengan pendidikan multikultural. Artikel ini menggambarkan peran seni musik dalam pendidikan multikultural yang dapat menumbuhkan kesadaran dan kepedulian dalam membangun masyarakat belajar yang multikultur di sekolah.
\end{abstract}

Kata kunci: globalisasi, seni musik, multikultur, transformasi, pendidikan

\section{THE ROLE OF MUSIC IN MULTICULTURAL EDUCATION}

\author{
Desyandri \\ Fakultas Ilmu Pendidikan Universitas Negeri Padang \\ desyandri@yahoo.co.id
}

\begin{abstract}
Indonesia is a multicultural country which has diverse cultures spreading from Sabang to Merauke, across thousands of islands with diverse cultures. The order has changed with globalization and the development of science, technology, and the arts (IPTEKS). Globalization also has an impact on inequality and injustice in the world of education. Education in general is the transfer of knowledge, experience and skills to the students so as to form a positive attitude and be enable to build a noble character in order to form the nation with regard the values of cultural diversity. Music art education provides the knowledge, experience, and competence through five basic components, namely: expression, appreciation, creation, harmony, and beauty which are integrated in multicultural education. This article describes therole of musicin multicultural education is to foster awareness and concern in establishing a multicultural learning community in schools.
\end{abstract}

Keywords: globalization, art of music, multicultural, education, transformation 


\section{PENDAHULUAN}

Negara Kesatuan Republik Indonesia (NKRI) terkenal dengan kemajemukannya dan merupakan negara dengan keanekaragaman etnis budaya dan agama. Penduduk Indonesia terdiri dari berbagai macam suku bangsa dengan keunikan identitas budayanya sendiri. Dilihat dari segi geografis Indonesia merupakan negara kepulauan dengan penduduk yang tersebar di daerah pegunungan, pesisir pantai dengan karakteristik lingkungan yang berbeda satu sama lain dan ditandai dengan adanya perbedaan strata sosial dan pertumbuhan ekonomi yang belum merata. Sesuai dengan falsafah negara Pancasila terutama sila ke lima yang mencita-citakan keadilan bagi seluruh rakyat Indonesia dan semboyan Bhinneka Tunggal Ika menunjukkan bahwa Indonesia adalah negara dengan penduduk yang multikultur.

Menyikapi kondisi multikultural yang terdapat di seluruh lini kehidupan berbangsa dan bernegara diperlukan upaya untuk tetap menumbuhkan kesadaran dan menjaga serta melestarikan keragaman tersebut. Agar terciptanya keadilan sosial dalam kehidupan manusia diperlukan aktivitas pendidikan yang mengakomodir seluruh keberagaman tersebut. Hal ini sejalan dengan pandangan $\mathrm{M}$. Nuh $(2012$, p.1) yang mengemukakan bahwa pendidikan dan kebudayaan berfungsi membangun karakter bangsa. Diharapkan kelak setiap warga negara memiliki nilai peradaban adiluhung yang mengakar dan membudaya dalam kehidupan sehari-hari. Pandangan ini memerlukan tindak lanjut untuk mensinergikan pendidikan dan kemajemukan kultur. Pendidikan memiliki peranan penting untuk menanamkan nilai-nilai keragaman budaya, sehingga nilai-nilai keragaman tersebut dapat membangun peradaban bangsa. Pandangan Ki Hadjar Dewantara (Ki Suratman, 1987, p.12) mengatakan bahwa pendidikan ialah usaha kebudayaan yang bermaksud memberi bimbingan dalam hidup tumbuhnya jiwa raga anak, agar dalam kodrat pribadinya serta pengaruh lingkungannya, mereka memperoleh kemajuan lahir batin menuju ke arah adab kemanusiaan.

Pendidikan merupakan produk budaya yang mengandung berbagai macam bidang kajian, diantaranya bidang kajian kesenian khususnya seni musik.Pendidikan seni musik memberikan pengetahuan, pemahaman, serta kompetensi pada peserta didik tentang keindahan (aestethica) yang dicerminkan melalui unsur-unsur ekspresi, apresiasi, dan harmoni. Sehingga dengan seni musik mereka dapat mengembangkan ekspresi jiwa, sikap apresiasi, dan dapat memberikan pengalaman dalam membentuk keharmonisasian dengan orang lain dan alam. Dengan kata lain, pada hakekatnya seni musik dapat menumbuhkan kesadaran peserta didik untuk tetap menjaga keseimbangan baik secara interpersonal, sosial, masyarakat, berbangsa, maupun menjaga keseimbangan dengan alam semesta. Kondisi ini menggambarkan bahwa seni musik juga memperhatikan keragaman dan perbedaan karakteristik yang dimiliki individu, sosial, masyarakat, dan negara. Salah satu sifat seni musik adalah memiliki dimensi multikultural. Sifat multikultural mengandung makna pendidikan seni musik menumbuhkembangkan kesadaran dan kemampuan apresiasi terhadap beragam budaya Nusantara dan Mancanegara. Hal ini merupakan wujud pembentukan sikap demokratis yang memungkinkan seseorang hidup secara beradab serta toleran dalam masyarakat dan budaya yang majemuk.

Seiring dengan globalisasi yang terjadi pada abad kedua puluh satu yang ditandai dengan pesatnya perkembangan ilmu pengetahuan, teknologi, dan seni di satu pihak dapat memberikan keuntungan dan kemudahan pada manusia dalam memperoleh informasi dan ilmu pengetahuan tanpa batas. Di lain pihak globalisasi merupakan sebuah momok mengerikan yang mengancam dan membahayakan, serta terjadinya perubahan sosial dan budaya manusia. Globalisasi dapat mengakibatkan kegoncangan budaya yang menyeret generasi muda untuk mencari jalan hidupnya sendirisendiri. Dalam percaturan globalisasi dapat ditengarai bahwa pengaruh positif dan negatif tidak berjalan secara seimbang. Hal ini dapat dijelaskan, bahwa dampak negatif globalisasi lebih mendominasi perubahan sosial-budaya masyarakat. Perkembangan ilmu pengetahuan, teknologi, dan seni melaju dengan cepat tanpa diikuti dengan perubahan sosial-budaya yang cepat pula, sehingga dampak yang muncul dapat ditengarai bahwa proses pendidikan dan keragaman budaya tidak lagi menunjukkan peran pentingnya dalam membangun peradaban bangsa. Khususnya terhadap peran penting pendidikan, keragaman budaya dalam 
menumbuhkembangkankesadaran untuk tetap mejaga keharmonisan baik dalam kehidupan individu, sosial, masyarakat, dan bangsa dalam kehidupan yang multikulutral menjadi terabaikan.

Realita dan permasalahan yang terjadi di lapangan, menunjukkan bahwa seni musik baik di persekolahan maupun perguruan tinggi masih memperlihatkan suatu kesenjangan, membeda-bedakan, ketidakadilan perlakukan secara akademis dan dominasi kultur tertentu. Serta adanya perilaku prasangka (prejudice) yang terlihat bahwa peserta didik yang berasal dari kalangan sosial ekonomi menengah ke bawah seakan-akan tidak berhak untuk meraih prestasi dan hasi belajar. Pada hal semua peserta didik memiliki kesempatan yang sama.

Permasalahan lain ditandai dengan munculnya permasalahan ketidakadilan (inequity), ketidaksetaraan (inequality), dan ketidakharmonisan, adanya disparitas, genderisme, dan perlakuan-perlakuan yang menghambat pengembangan kompetensi peserta didik dalam pembelajaran. Dengan kata lain kurangnya kesadaran, perilaku apresiasi, dan harmonisasi baik itu dari aspek pendidik, peserta didik, sekolah maupun di lingkungan budaya masyarakat.

Berdasarkan fakta dan permasalahan yang dikemukakan di atas yang berkaitan dengan permasalahan dan pengabaian kultur dalam pendidikan memerlukan suatu terobosan dan gerakan dalam bidang pendidikan yang minimal dapat memberikan salah satu solusi untuk menumbuhkan kesadaran (awareness), dan pemahaman terhadap perubahan pola dan kehidupan berbudaya manusia agar terselenggaranya pendidikan yang mewadahi aspek-aspek karakteristik budaya manusia. Berikut ini dilakukan analisis dan pengkajian seni musik yang terintegrasi dengan pendidikan multikultural yang diyakini dapat memberikan pemecahan masalah (problem solving) terhadap permasalahan-permasalahan pendidikan terkait dengan ketidakadilan dan ketidaksetaraan budaya, sehingga memunculkan pemikiran kritis dan terlaksanannya pendidikan yang sangat bermakna (meaningfull).

\section{PEMBAHASAN}

Berdasarkan permasalahan yang ditemui tentang pendidikan seni musik dan pendidikan multikultural, berikut ini akan dilakukan pengkajian dan analisis secara kon- septual terhadap peran penting seni musik dalam pengembangan pendidikan multikultural di Indonesia.

\section{Konsep Pendidikan}

Menurut Brown (1970, pp.52-53) mengemukakan tentang filosofi pendidikan sebagai berikut:

For education, when it is genuinely educational, brings about not only acquisition of knowledge and skills, but it form also attitudes and dispositions that direct the uses to which acquired information and skill are put. While not as yet the most powerful existing agency in the formation of the disposition of individuals in its active relation to social needs and values, it tis the one agency that deals deliberately and intentionally with the practical solution of the basic relation of the individual and the social. Moreover, it has to do with perpertuaton of the positive values of inherited culture by embodying them in the disposition of individual who are to transmit culture into the future, and also whit the creation of attitudes, understanding, and desire that will produce a better future culture.

Pendidikan yang sebenarnya bukan hanya kemahiran pengetahuan dan keterampilan, tetapi juga membentuk sikap dan watak dari hubungan individu dan sosial yangmembawa pewarisan nilai-nilai positif budaya serta pembentukan sikap, pemahaman, dan hasrat untuk masa depan budaya yang lebih baik. Filosofi pendidikan ini sangat terkait dengan pengkajian terhadap pendidikan, seni musik, dan pendidikan multikultural yang ketiganya terkait dengan budaya. Ditinjau dari fungsi pendidikan menurut undang-undang Sistem Pendidikan Nasional (Sisdiknas) No. 20 Tahun 2003 Bab. II, Pasal 3 dinyatakan bahwa: "Pendidikan nasional berfungsi mengembangkan kemampuan membentuk watak serta peradaban bangsa yang bermartabat dalam rangka mencerdaskan kehidupan bangsa, bertujuan untuk berkembangnya potensi peserta didik agar menjadi manusia yang beriman dan bertaqwa kepada Tuhan Yang Maha Esa, berakhlak mulia, sehat, berilmu, cakap, kreatif, mandiri, dan menjadi warga negara yang demokratis, serta bertanggung jawab". Dua pandangan di atas 
menjelaskan bahwa pendidikan secara umum merupakan pemberian pengetahuan, pengalaman dan keterampilan kepada peserta didik sehingga dapat membentuk perilaku positif dan dapat membangun karakter mulia dalam upaya membentuk peradaban bangsa dengan memperhatikan nilai-nilai dalam keragaman budaya yang dimiliki bangsa Indonesia.

\section{Konsep Seni Musik}

Plato berpendapat tentang musik dalam Seymour \& Harriet Ayer (1920, p.164) yang mengatakan bahwa, "Music is a moral law. It gives soul to the universe, wings to the mind, flight to the imagination, and charm and gaiety to life and to everything". Pendapat tersebut menggambarkan bahwa seni musik merupakan bahasa emosi manusia terhadap alam semesta baik alam itu sendiri maupun manusia yang menghuni alam tersebut yang memiliki akal dan pikiran serta imajinasi untuk tetap menjalani kehidupan sehari-hari dengan ekpresi, sikap dan perilaku yang saling menghargai (apresiasi), serta berusaha untuk membentuk harmonisasi atau keseimbangan.

Selanjutnya pendapat Plato tersebut dikembangkan lagi oleh Friedmann (1980, p.100) yang mengatakan bahwa:

Music is the language of emotion. Emotion is connected with thought. Thought is connected with action, action deals with conduct, and the sphere of conduct is connected with morals. Therefore, ladies and gentlemen, if music is connected with emotion, and emotion is connected with thought, and thought is connected with action, and action is connected with the sphere of conduct, or with morals, things which are connected by the same must be onnected with one another, and therefore music must be connected with morals.

Musik adalah bahasa emosi dan emosi selalu terhubung dengan pikiran manusia. Pemikiran terhubung dengan tindakan (action), tindakan berkaitan dengan perilaku, dan bidang perilaku terhubung dengan moral. Sejalan dengan Djohan (2009, p.170) juga mengemukakan bahwa musik juga sebagai alat untuk meningkatkan dan membantu perkembangan kemampuan pribadi. Perkembangan pribadi meliputi aspek kompetensi kognitif, penalaran, inteligensi, kreativitas, membaca, bahasa, sosial, perilaku, dan interaksi sosial. Kedua pandangan ini memberikan gambaran bahwa seni musik secara konseptual pendidikan seni musik dapat memberikan bekal pengalaman kepada peserta didik untuk dapat membentuk interaksi, komunikasi, keadilan, kesetaraan, keharmonisan, dan keindahan dalam keberagaman karakteristik individu (pemain) dan keberagaman bentuk alat musik yang terlibat dalam sebuh performan musik. Hal ini jelas menggambarkan suatu perpaduan budaya yang berbaur menjadi satu dengan mempertimbangkan azas keharmonisan dan keindahan. Sehingga dengan adanya bentuk manipulasi masyarakat multikultur dalam peforma musik seharusnya dapat memberikan gambaran pada kehidupan manusia yang multikultur. Dengan kata lain pendidikan seni musik mengakomodir perbedaan dan kemajemukan kultur baik yang dimiliki oleh individual, sosial, dan budaya.

\section{Konsep Pendidikan Multikultural}

Kesatuan dan keragaman merupakan tujuan dan ideologi bangsa yang terkenal dengan Pancasila, serta makna yang terkandung dalam semboyan Bhinneka Tunggal Ika, serta makna yang terkandung dalam isi Sumpah Pemuda pada tahun 1928 dan sekaligus merupakan tantangan dan juga dapat memungkinkan terjadinya permasalahan yang melanda bangsa Indonesia yang terus berlanjut dan seakan-akan tidak ada akhirnya. Menurut James A. Banks (2006, p.208) mengamukakan tentang perlunya keseimbangan antara kesatuan dan keberagaman:

Balancing unity and diversity is a continuing challenge for multicultural nationstates. Unity without diversity results in hegemony and oppression; diversity without unity leads to Balka-nization and the fracturing of the nation-state. A major problem facing nation-states throughout the world is how to recognize and legitimize difference and yet construct an overarching national identity that incorporates the voices, experiences, and hopes of the diverse groups that compose it. Many ethnic, language, and religious groups have weak identifications with their nation-state because of their marginalized status and because they do not 
see their hopes, dreams, visions, and possibilities reflected within the nation-state or within the schools, colleges, and universities (Ladson-Billings, 2004).

Pendapat ini menggambarkan perlunya keragaman dalam rangka untuk mencapai suatu kesatuan dalam negara atau bangsa. Jika hal ini tidak dilakukan, maka akan berdampak pada penindasan kultur, etnis, bahasa, dan agama yang sekaligus menjadikan mereka tidak memiliki harapan untuk hidup dalam suatu negara atau bangsa.

Pemikiran lain juga dikemukakan oleh James A. Banks (2006, p.201) menyatakan bahwa:

Diversity also provides schools, colleges, and universities with an opportunity to educate students in an environment that reflects the reality of the nation and the world and to teach students from diverse groups how to get along and how to make decisions and take actions that promote social justice. A diverse school environment enables students from many different groups to engage in discussions to solve complex problems related to living in a multicultural nation and world.

Keanekaragaman juga menetapkan sekolah, perguruan tinggi, dan universitas untuk mendidik siswa dalam lingkungan yang mencerminkan realitas bangsa dan dunia dari beragam kelompok, bagaimana bergaul dan bagaimana membuat keputusan dan kegiatan yang mempromosikan keadilan sosial. Sebuah lingkungan sekolah yang beragam memungkinkan siswa dari berbagai kelompok untuk terlibat dalam diskusi untuk memecahkan masalah kompleks yang berkaitan dengan hidup di negara multikultural dan dunia.

Secara historis pendidikan multikultural lahir di Amerika Serikat terkait dengan adanya perbedaan dan permasalahan terhadap rasial, gender, etnik, kesenjangan ekonomi dan politik, status sosial, dan pluralitas agama dal lain-lain. Hal ini menumbuhkan pemikiran kritis James A. Banks dalam menyikapi permasalahan yang melanda Amerika. Dari beberapa permasalahan di Amerika, dapat diambil beberapa permasalahan yang juga terkait dan terjadi di Indonesia, seperti ketidakadilan, kesenjangan, kemajemukan, pluralitas agama, dan kesetaraan. Lebih khususnya lagi kesen- jangan dalam bidang pendidikan yang samasama terdiri dari masyarakatmulti etnik, multi religius, dan multikultur. Sehingga konsep dan pengimplementasian Pendidikan Multikultural sesuai dan dapat diterapkan di Indonesia. Untuk itu diperlukan upaya untuk merubah pendidikan yang dilakukan secara monokultural menjadi pendidikan yang mengakomodir seluruh keragaman dan perbedaan karakteristik peserta didik.

Menurut John Drummond (2005, p.1) bahwa:

The new sociologists pointed out that educating all children in the dominant culture privileged those who came from that culture; children from a different class or ethnicity tended to perform poorly. Following Bourdieu, they argued that schools are locales in which the dominant culture engages in symbolic violence against social groups disadvantaged by the monocultural curriculum. The answer, it was suggested, was to introduce more multicultural elements.

Para sosiolog baru menunjukkan bahwa mendidik semua peserta didik yang berada dalam budaya dominan yang memiliki hak istimewa dapat menguasai budaya tersebut. Dan orang-orang yang berasal dari kelas atau etnis yang berbeda cenderung berkinerja buruk. Mereka berpendapat bahwa sekolah di mana budaya yang dominan terlibat dalam kekerasan simbolik terhadap kelompok sosial yang dirugikan oleh kurikulum monokultural, dan menyarankan untuk memperkenalkan elemen yang lebih multikultural.

Zamroni (2011, p.140) menyatakan bahwa pendidikan multikultural merupakan suatu bentuk reformasi pendidikan yang bertujuan untuk memberikan kesempatan yang setara bagi semua siswa tanpa memandang latar belakangnya, sehingga semua siswa dapat meningkatkan kemampuan yang secara optimal sesuai dengan ketertarikan, minat dan bakat yang dimiliki. Pendidikan multikultural memberikan penyadaran sekaligus arahan bagi terciptanya proses pembelajaran yang menjunjung tinggi karakteristik dan kenyamanan peserta didik yang akan berdampak pada peningkatan kompetensi dan hasil belajar mereka. Di samping itu, pendidikan multikultural dapat diberlakukan sebagai alat bantu untuk menjadikan warga masyarakat 
lebih memiliki karakter toleran, bersifat inklusif, dan memiliki jiwa kesadaran dalamhidup bermasyarakat, serta senantiasa berpendirian suatu masyarakat secara keseluruhan akan lebih baik, manakala siapa saja warga masyarakat memberikan kontribusi sesuai dengan kemampuan dan kesempatan yang dimiliki bagi masyarakat sebagai keutuhan. Dengan kata lain, diperlukan pendidikan yang dapat menumbuhkan kesadaran akan pentingnya kondisi keberagaman, baik secara individu, sosial, masyarakat, maupun dalam kehidupan bernegara.

Pendidikan multikultral memiliki sifat seperti yang dijelaskan James A. Bank (2010, p.3) menyatakan bahwa:

Multicultural education is at least three things: an idea or concept, an educational reform movement, and a process. Multicultural education incorporates the idea that all students-regardless of their gender, social class, and ethnic, racial, or cultural characteristics-should have an equal opportunity to learn in school. Another important idea in multicultural education is that some students, because of these characteristics, have a better chance to learn in schools as they are currently structured than do students who belong to other groups or who have different cultural characteristics.

Pendidikan multikultural setidaknya memiliki tiga hal, yakni: ide atau konsep, sebuah gerakan reformasi pendidikan, dan proses. Pendidikan multikultural menggabungkan ide bahwa semua peserta didik tanpa memandang jenis kelamin mereka, kelas sosial, dan etnis, ras, atau budaya karakteristik harus memiliki kesempatan yang sama untuk belajar di sekolah. Gagasan lain yang penting dalam pendidikan multikultural adalah bahwa siswa, memiliki kesempatan yang lebih baik untuk belajar di sekolah seperti yang saat ini terstruktur daripada siswa yang berasal dari kelompok lain atau yang memiliki budaya yang berbeda karakteristik.

James A. Banks (2006, p.202) mengemukakan tentang tujuan pendidikan multikultural adalah:

An important goal of multicultural education is to improve race relations and to help all students acquire the knowledge, attitudes, and skills needed to participate in cross-cultural interactions and in personal, social, and civic action that will help make our nation and world more democratic and just. The goal of multicultural education is to teach students to know, to care, and to act to promote democracy and social justice.

Tujuan pendidikan multikultural adalah membantu meningkatkan perilaku kesadaran dan kepedulian unsur-unsur pendidikan baik itu pendidik, peserta didik, masyarakat, maupun lembaga pendidikan terhadap permasalahan kultur dan interaksi lintas kultur dalam rangka mewujudkan demokrasi dan ketidakadilan.

James A. Banks (2006, pp.203-207) juga menyatakan bahwa pendidikan multikultural memiliki 5 dimensi, yakni: (1) content integration, (2) the knowledge construction process, (3) prejudice reduction, (4) an equity pedagogy, and (5) an empowering school culture and social structure.

Pendapat yang sama tentang dimensi pendidikan multikultural juga dikemukakan oleh Phi Delta Kappan1993 dalam James A Banks (2006, pp.129-138) mengatakan bahwa pendidikan multikultural menggunakan lima dimensi berikut untuk menggambarkan komponen utama dari lapangan tersebut dan untuk menyoroti perkembangan penting dalam dua dekade terakhir: (1) integrasi konten, (2) konstruksi proses pengetahuan, (3) reduksi prasangka, (4) kesetaraan pedagogi, dan (5) pemberdayaaan kultur sekolah dan struktur sosial.

a. Konten Integrasi; berkaitan dengan sejauh mana guru menggunakan contoh, data, dan informasi dari berbagai budaya dan kelompok untuk mengilustrasikan kunci konsep, prinsip, generalisasi, dan teori-teori di daerah subjek atau disiplin mereka. Konten integrasi menggambarkan pola pembelajaran terintegrasi yang memberikan pengetahuan dan pengalaman pada peserta didik dengan menggunakan menggunakan contoh-contoh, fakta, dan informasi yang mengilustrasikan keberagaman budaya yang ada, baik di lingkungan sekolah, daerah, nasional, maupun internasional.

b. Konstruksi Pengetahuan; meliputi prosedur dimana perilaku sosial, ilmuwan, dan alam menciptakan pengetahuan dalam disiplin ilmu mereka. Sebuah multikul- 
tural berfokus pada konstruksi pengetahuan yang meliputi diskusi tentang cara-cara di mana budaya diasumsikan secara implisit, kerangka acuan, perspektif, dan bias dalam disiplin yang mempengaruhi proses konstruksi pengetahuan. Pengkajian pengetahuan pada proses konstruksi merupakan bagian penting dari pendidikan multikultural. Guru membantu siswa untuk memahami bagaimana pengetahuan dibuat dan bagaimana hal itu dipengaruhi oleh faktor ras, gender etnis, dan kelas sosial.

c. Reduksi Prejudice; berfokus pada karakteristik sikap rasial peserta didik dan pada strategi yang dapat digunakan untuk membantu siswa mengembangkan sikap rasial dan etnis yang lebih positif. Sejak tahun 1960, ilmuwan sosial telah belajar banyak tentang bagaimana sikap rasial pada anak-anak mengembangkan dan tentang cara-cara di mana pendidik dapat merancang intervensi untuk membantu peserta didik memperoleh perasaan lebih positif terhadap kelompok ras lainnya.

a. Peserta dapat membantu mengembangkan sikap rasial yang lebih positif jika gambaran realistis dari kelompok etnis dan ras termasuk dalam sebuah konten/ materi pengajaran, secara konsisten alami, dan terintegrasi. Melibatkan peserta didik dalam perwakilan pengalaman dan kegiatan pembelajaran kooperatif dengan siswa dari ras lainnya, kelompok juga akan membantu mereka untuk mengembangkan sikap rasial dan perilaku yang lebih positif.

b. Hal ini memberikan gambaran bahwa pemberian pengetahuan dan pengalaman dalam rangka untuk memberikan kesadaran pada peserta didik akan keberagaman kultur, maka diperlukan strategi untuk memberikan pengalaman, kuantitas dan kualtias interaksi, saling membantu baik dalam sosialisasi maupun dalam kelompok pembelajaran. Sehingga dapat terbentuk kerjasama antarkultur yang beragam dan berdampak pada reduksi prasangka yang bersifat negatif terhadap masing-masing peserta didik.

d. Kesetaraan Pedagogi; dapat diujudkan ketika guru menggunakan teknik dan metode pengajaran yang memfasilitasi prestasi akademik peserta didik dari ras dan etnis yang beragam dalam kelompok dan dari semua kelas sosial. Menggunakan teknik pengajaran yang melayani pembebelajaran dan gaya budaya kelompok yang beragam dan menggunakan teknik kerjasama pembelajaran dalam berbagai cara. Ini menggambarkan bahwa guru telah terbukti secara efektif memberikan dan memunculkan pengetahuan, pengalaman, kesadaran dan sikap peduli pada masing-masing peserta didik yang terdiri dari beragam ras, etnis bahasa, dan group.

e. Pemberdayaan Budaya Sekolah dan Struktur Sosial; membutuhkan restrukturisasi budaya dan organisasi sekolah sehingga peserta didikyang terdiri dari ras yang beragam, kelompok etnis, dan kelas sosial akan mengalami kesetaraan pendidikan dan rasa pemberdayaan. Dimensi pendidikan multikultural melibatkan konseptualisasi sekolah sebagai unit perubahan dan membuat perubahan struktural dalam lingkungan sekolah. Mengadopsi teknik penilaian yang adil bagi semua kelompok, melakukan pelacakan, dan menciptakan kepercayaan di antara guru dan semua peserta didik bahwa semua peserta didik dapat belajar yang juga merupakan tujuan penting bagi sekolah yang ingin membangunbudaya sekolah dan struktur sosial yang memberdayakan dan meningkatkan peran untuk keberagaman peserta didik.

Zamroni (2011, pp.156-157) menyatakan pendidikan multikultural memiliki tiga sasaran. Pertama, pengembangan identitas kultural yakni merupakan kompetensi yang dimiliki siswa untuk mengidentifikasi dirinya dengan suatu etnis tertentu. Kompetensi ini mencakup pengetahuan, pemahaman, dan kesadaran akan kelompok etnis dan menimbulkan kebanggaan serta percaya diri sebagai warga kelompok etnis tertentu. Kedua, hubungan interpersonal. Kompetensi untuk melakukan hubungan dengan kelompok etnis lain, dengan senantiasa mendasarkan pada persamaan dan kesetaraan, serta menjauhi sifat syak wasangka dan stereotip. Ketiga, memberdayakan diri sendiri. Yakni suatu kemampuan untuk mengembangkan secara terus menerus apa yang dimiliki berkaitan dengan 
kehidupan multikultural. Ketiga sasaran ini merupakan kompetensi kultural.

Secara lebih detail, kompetensi kultural mencakup berbagai hal, antara lain: (a) kemampuan individu untuk menerima, menghormati dan membangun kerjasama dengan siapapun juga yang memiliki perbedaanperbedaan dari dirinya; (b) kompetensi kultural merupakan hasil dari kesadaran atas pengetahuan dan "bias kultural" yang dimilikinya sebagai faktor yang mempengaruhi perbedaan kultur; (c) proses pengembangan kompetensi kultural memerlukan pengembangan pengetahuan, keterampilan, sikap dan perilaku yang memungkinkan seseorang memahami dan ber-interaksi secara efisien dengan orang yang memiliki perbedaan kultur.

\section{Peran Seni Musik dalam Pendidikan Multikultural}

Berdasarkan gambaran konsep pendidikan, seni musik dan pendidikan multikulutal yang terah dijelaskan sebelumnya menjadi acuan tentang peran seni musik dalam pendidikan multikultural yang akan dipaparkan di bawah ini. Secara konseptual seni musik terhubung erat dengan pendidikan multikultural, hal ini dikarenakan karya seni musik secara konseptual terlahir melalui pemikiran dan ideide tentang kultur pencipta ataupun kultur dari beragam orang. Dari pengolahan pemikiran tersebut lahirlah sebuah karya seni yang juga menggambarkan tentang manifestasi alam, individu, masyarakat, dan bahkan sebuah bangsa yang kesemuanya itu tidak terlepas dari gambaran karekteristik kultur serta peserta didik dapat berinteraksi dan berkomunikasi secara interkultural.

Menurut Marsh (2005, p.38) dalam prosiding Cultural Diversity in Music Education mengemukakan bahwa:

Music occupies a significant place in world cultures and the recorded history of all civilisations. ... Music has the capacity to cross cultural and societal boundaries. It plays a variety of important roles in the cultural and spiritual lives of people. ... The study of music ... allows for the expression of the intellect, imagination and emotion, the exploration of values, and fosters an understanding of continuity and change, as well as connections between different times and cultures (Board of Studies NSW, 1999a, p. 6, 1999b, p. 6).

Musik menempati tempat yang signifikan dalam budaya dunia dan sejarah mencatat dari semua peradaban. Musik memiliki kapasitas untuk menyeberangi batas-batas sosial dan budaya. Ini memainkan bermacam-macam peran penting dalam kehidupan budaya dan spiritual masyarakat. Penelitian musik memungkinkan untuk ekspresi imajinasi, intelektual dan emosi, eksplorasi nilai-nilai, dan mendorong pemahaman tentang kesinambungan dan perubahan, serta koneksi antara waktu yang berbeda dan budaya.

Pendidikan seni musik dapat memberikan peranan yang signifikan terhadap pelaksanaan pendidikan multikultural di Indonesia. Peran ini mengacu pada lima dimensi yang dikemukakakan oleh James A. Banks, yakni; (1) content integration; (2) the knowledge construction process; (3) prejudice reduction; (4) an equity pedagogy; and (5) an empowering school culture and social structure yang dikaitkan dengan lima unsur utama konten pendidikan seni musik yang teritegrasi dengan pendidikan multikultural, yakni; (1) ekspresi; (2) apresiasi; (3) kreasi; (4) harmoni; dan (5) estetika pada proses pembelajaran di persekolahan. Secara konseptual sama-sama memiliki tujuan untuk membantu pendidik dalam pengembangan identitas etnik, hubungan interpersonal, pemberdayaan diri. Ketiga dimensi ini harus dioperasionalisasikan sebagai dukungan terhadap lima dimensi pendidikan multikulutral untuk mengembangkan sosial dan kognitif peserta didik (Zamroni, 2001a, p.77).

Kerangka pikir peran seni musik dalam pendidikan multikultural dapat disajikan dalam skema berikut: 


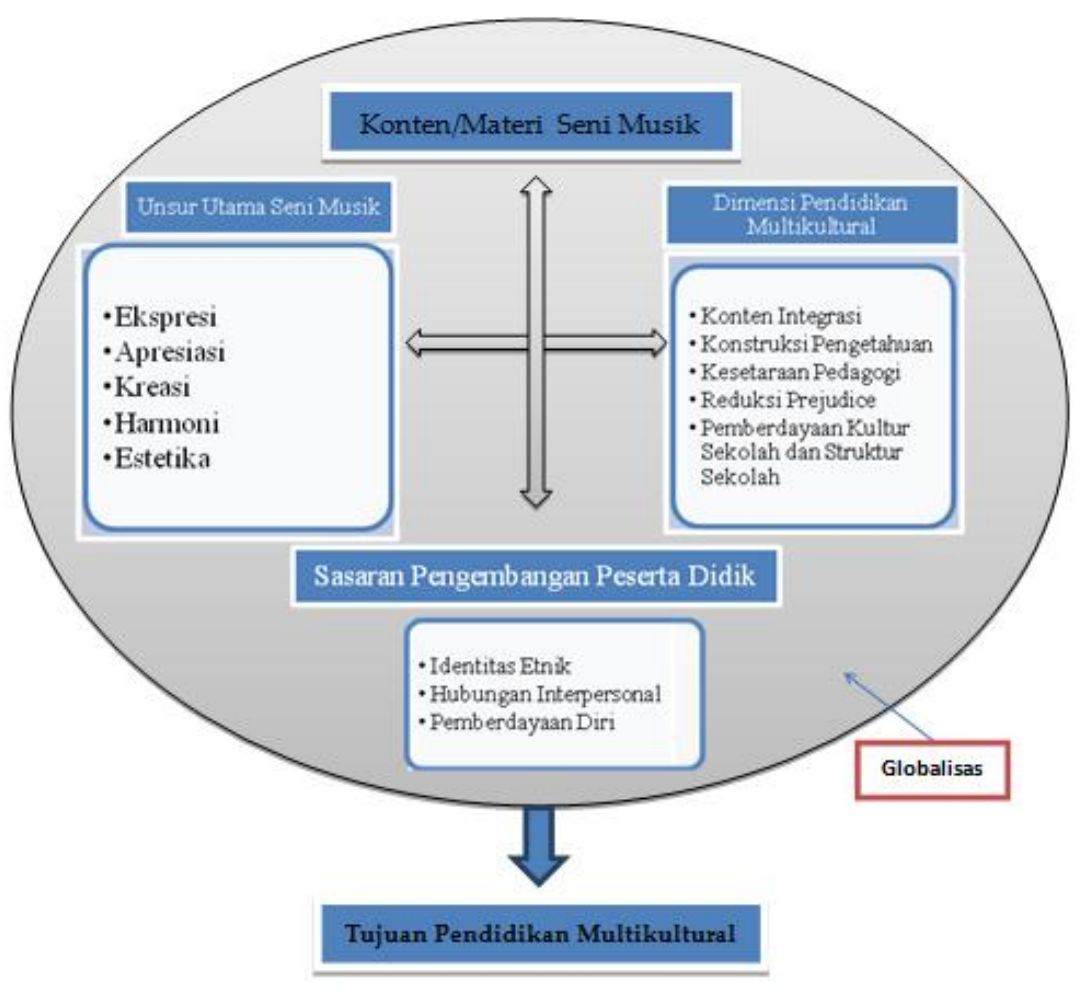

Gambar 1.

Berdasarkan skema kerangka konseptual dalam pengkajian peran seni musik dalam pendidikan multikultural yang terintegrasi dapat digambarkan dengan sebuah konten seni musik yang diberikan dengan memfasilitasi dan mengakomodir keberagaman masingmasing individu peserta didik maupun keragaman budaya masing-masing daerah, serta budaya nasional Indonesia dalam rangka menyikapi arus globalisasi.

Konsep pembelajaran merupakan pengintegrasian konsep seni musik dengan lima dimensi dan disertai dengan tiga dimensi pendukung pendidikan multikultural. Sehingga konsep pembelajaran dapat menggambarkan peran seni musik dalam pendidikan multikultural. Proses konstruksi pengetahuan meliputi prosedur ilmiah yang meliputi diskusi tentang cara-cara di mana budaya diasumsikan secara implisit, kerangka acuan, perspektif, dan bias dalam disiplin yang mempengaruhi proses konstruksi pengetahuan. Guru memfasilitasi peserta didik untuk melakukan penelitian sederhana yang dimulai dengan asumsi-asumsi tentang lagu daerah dan melakukan prosedur secara ilmiah, agar peserta didik dapat memahami bagaimana lagu daerah itu diciptakan dan bagaimana pengaruh faktor ras, gender, etnis, dan kelas sosial masyarakat yang berada di lingkungan sekitar lagu daerah tersebut diciptakan. Proses konstruksi pengetahuan juga dapat dilakukan dengan diskusi ilmiah tentang lagu daerah, misalnya merumuskan tentang defenisi, analisis konten lagu daerah, dan nilai-nilai pendidikan yang terdapat pada lagu daerah tersebut dan pada akhir pembelajaran ditutup dengan review refleksi terhadap pembelajaran yang dilakukan dan pengambilan kesimpulan yang dipandu oleh pendidik.

Reduksi prasangka (prejudice reduction) terfokus pada karakteristik sikap rasial peserta didik dan pada strategi yang dapat digunakan untuk membantu siswa mengembangkan sikap rasial dan etnis yang lebih positif. Pendidik dapat membentuk kelompok dalam performa terhadap lagu daerah, sehingga akan membantu peserta didik untuk berinteraksi, berkomunikasi, dan menumbuhkan sikap toleransi sesama mereka. Strategi ini dapat memberikan pengalaman dan kesadaran, serta kepedulian peserta didik akan keberagaman kultur, dan akhirnya akan mengurangi prasangka terhadap etnis sesama peserta didik atau etnis kelompok lain. Sehingga dengan pengurangan prasangka 
justru akan menumbuhkan sikap terbuka dan terjalinnya kerjasama, serta iklim kultur yang positif.

Kesetaraan pedagogi dapat diujudkan dengan menggunakan teknik dan metode pengajaran yang memfasilitasi prestasi akademik peserta didik dari ras dan etnis yang beragam dalam kelompok dan dari semua kelas sosial. Pendidik memfasilitasi peserta didik untuk menumbuhkan iklim akademik yang kondusif dengan memberikan kesetaraan dan tidak mengabaikan keberagaman budaya baik tentang lagu daerah maupun tentang keragaman budaya yang dimiliki oleh peserta didik dalam pembelajaran. Sehingga dapat menumbuhkan pengetahuan, pengalaman, kesadaran dan sikap peduli pada masingmasing peserta didik yang terdiri dari beragam ras, etnis bahasa, dan kelompok.

Setelah empat dimensi pendidikan multikultural dapat diterapkan, maka proses selanjutnya adalah mengembangkan pemberdayaan budaya sekolah dan struktur sosial yang lebih kompleks dan membutuhkan restrukturisasi budaya dan organisasi sekolah sehingga peserta didik yang terdiri dari ras yang beragam, kelompok etnis, dan kelas sosial akan mengalami kesetaraan pendidikan dan rasa pemberdayaan.

Mengadopsi teknik penilaian yang adil bagi semua kelompok, melakukan pelacakan, dan menciptakan kepercayaan di antara guru dan semua peserta didik bahwa semua peserta didik dapat belajar dan sekligus merupakan tujuan penting bagi sekolah untuk membangun budaya sekolah dan struktur sosial yang memberdayakan dan meningkatkan peran untuk keberagaman peserta didik. Dimensi ini merupakan tahap akhir pendidikan multikultural yang terbentuk dan diawali dari proses transforamsi diri/individu, sekolah, dan transformasi masyarakat yang melibatkan konseptualisasi sekolah sebagai unit perubahan dan membuat perubahan struktural dalam lingkungan sekolah. Dan pada akhirnya menekankan untuk melaksanakan tujuan utama dari pendidikan multikultural yakni untuk merestrukturisasi kultur sekolah dan struktur sosial sehingga semua peserta didik akan memperoleh pengetahuan, pemahaman, sikap, dan keterampilan yang dibutuhkan untuk berfungsi dalam bangsa dan dunia yang beragam etnis dan ras, serta memberikan jaminan pada semua peserta didik dengan latar belakang yang berbeda merasa mendapat pengalaman dan perlakuan yang setara.

Setelah pelaksanaan proses pembelajaran seni musik dengan konten lagu daerah nusantara yang terintegrasi dengan kelima dimensi pendidikan multi kulutral dan berdasarkan perspektif hasil pembelajaran, memiliki tiga sasaran yang dikembangkan pada setiap diri peserta didik. Pertama, pengembangan identitas kultural. Peserta didik memiliki kompetensi untuk mengidentifikasi dirinya dengan suatu etnis yang lain sehingga menumbuhkan rasa kebanggaan serta percaya diri sebagai warga kelompok etnis tertentu. Kedua, hubungan interpersonal. Peserta didik dapat melakukan hubungan dengan kelompok etnis lain, dengan senantiasa mendasarkan pada persamaan dan kesetaraan, serta menjauhi sifat syak wasangka dan stereotip. Ketiga, memberdayakan diri sendiri. Peserta didik memiliki kemampuan untuk mengembangkan secara terus menerus apa yang dimiliki berkaitan dengan kehidupan multikultural.

Berdasarkan penjelasan di atas didentifikasi beberapa peran seni musik dalam pendidikan multikultural dari sisi peserta didik sekaligus dapat berperan dan memberikan solusi pemecahan masalah bagi pendidik, sekolah, lingkungan sosial masyarakat, dan bangsa Indonesia yang mengacu pada konsep pendidikan seni musik terkait konten lagu daerah nusantara yang terintegrasi dengan pendidikan multikultural. Pertama, memberikan kesempatan dan pengalaman berekspresi kepada peserta didik dalam rangka mengakomodir rasa berseni musik (sense of art) mereka serta menumbuhkan dan menanamkan kesadaran akan keragaman budaya yang dimiliki oleh bangsa Indonesia. Kedua, memberikan kesempatan dan menumbuhkan sikap apresiasi terhadap kekayaan dan keanekaragaman budaya nusantara sebagai basis budaya nasional pada zaman globalisasi. Dan memberikan kontribusi terhadap pelestarian warisan budaya daerah. Ketiga, peserta didik dapat berkreasi dan menciptakan identitas kultur mereka sendiri yang tetap memberikan perhatian pada budaya-budaya nusantara atau budaya nasional yang sudah ada. Keempat, peserta didik dapat mengurangi prasangka dan stereotip, serta membentuk hubungan dan komunikasi, serta menjaga harmoni atau keseimbangan dengan budaya-budaya yang ada, 
dan menyadari sepenuhnya bahwa setiap budaya memiliki keunikan tersendiri. Kelima, peserta didik dapat melihat keindahan dan kemolekan masing-masing budaya, dan berusaha untuk tetap melestarikannya, serta dapat menjadikan keragaman budaya sebagai sebuah kekuatan dalam membangun budaya dan karakter bangsa Indonesia untuk masa yang akan datang.

Berikut ini akan diberikan contoh pendidikan seni musik terintegrasi dengan pendidikan multikultur, yaitu dengan mengapresiasi dan mengekspresikan musik dan lagulagu daerah nusantara yang memiliki karakteristik dan keberagaman alat musik maupun keberagaman ritme/irama yang khas untuk masing-masing daerah. Lagu-lagu tersebut dapat diekspresikan baik secara solo ataupun secara bersama-sama (paduan suara/ansambel). Sehingga dapat diciptakan suasana komunitas belajar (learning community) yang dapat memunculkan suasana multikultur, baik dalam materi/kurikulum maupun dalam penggunaan metode pembelajaran yang dapat membantu peserta didik untuk memahami keberagaman dan karakteristik individu serta keberagaman dan kekhasan masing-masing budaya.

Ekplorasi konten pembelajaran dengan lima unsur utama seni musik yang dibantu dengan penyediaan fasilitas/alat musik pada pembelajaran tentang musik dan lagu daerah dapat memberikan pengetahuan, pemahaman, pengalaman, performan dapat menumbuhkan kepedulian dan kesadaran untuk berpartisipasi langsung terhadap budaya-budaya daerah di Indonesia sebagai basis budaya nasional Indonesia. Selain budaya daerah sendiri, peserta didik dapat juga diperkenalkan budaya daerah lain yang akan memperkaya pengetahuan, pengalaman yang dapat menumbuhkan kesadaran dan kepedulian mereka terhadap rasa persaudaraan sebagai satu bangsa dan satu negara yakni NKRI.

\section{SIMPULAN}

Indonesia sebagai negara multikultur yang terdiri dari beragam budaya bukan dilihat sebagai sebuah kelemahan atau kendala, akan tetapi keberagaman seharusnya dapat diberdayakan sebagai kekuatan untuk mencapai tujuan, khususnya pendidikan.
Globalisasi dan pengembangan IPTEKS yang mengakibatkan perubahan pola kehidupan dan budaya, dapat diatasi dengan meningkatkan peran seni musik dalam membantu gerakan progresif pendidikan multikultural yang dampak terhadap peningkatan kesadaran (awareness) dan pemahaman (understanding) akan pengakuan hak isti-mewa (privilage) peserta didik dalam keberagaman kultur, sehingga pengakuan dan pemahaman antarbudaya (cross-cultural) tersebut akan berdampak pada kenyamanan suasana belajar dan akhirnya akan meningkatkan prestasi dan hasil belajar peserta didik.

\section{DAFTAR PUSTAKA}

Banks, James A \& Herry A McGee Banks. (2005). Multicultural education; Issues and perspectives. Fifth edition update. United State of America: John Wiley \&Sons, Inc

Banks, James A. (2006). Race, culture, and education; the selected work of James A. Banks. Multicultural Edition I. London and New York: Rouledge, Taylor and Francis Group

(2007). Educating citizens is a multicultural society; Second edition. Columbia University: Teachers College

Brown, Leslie M. (1970). Aims of education. New York: Columbia University; Teacher College Press

Colwell, Richard J. (1991). Basic consept in music education, II. Colorado: University Press of Colorado

Darling-Hammond, Linda dkk. (2002). Learning to Teach for Social Justice; Multicultural Education Series James A. Banks, Series Editor.

Drummond, John dkk. (2005). Cultural diversity in music education; directions and challenges for the 21st century. Australia: Australia Academic Press

Friedmann, Jonathan L.. (1980). The Value of Sacred Music; an Anthology of Essential Writings 1801-1918. Jefferson, North Carolina, \& London: McFarland \& Company Inc., Publishers 
Ki Suratman. (1987). Pokok-pokok Ketamansiswaan. Yogyakarta: Majelis Luhur Persatuan Taman Siswa.

Ladson-Billing, Gloria \& David Gilborn. (2004). The Routledge Falmer Reader in Multicultural Education. London \& Newyork. RoutledgeFalmer Taylor and Francis Group

Mans, Minette. (2009). Living in World of Music; A View of Education and Value. In Lanscape the Art, Aesthetic, and Education. Volume 8. New York: Springer

M. Nuh. (2012). Memadukan Program Kebudayaan dengan Pendidikan. Majalah Dikbud Edisi No. 6 Tahun III Desember 2012. Jakarta: Kementerian Pendidikan dan Kebudayaan

Noel, Jana. (2000). Sources; Notable Selection in Multicultural Education. Monta- na State University: Dushkin/McGrawHill

Seymour, Harriet Ayer. (1920). The Philosophy of Music. New York and London: Harper and Brother Publisher

Stephenson, Joan, dkk. (2005). Value in Education. New York: Routledge

Tilaar, H.A.R. (2010). Paradigma Baru Pendidikan Nasional. Jakarta: Rineka Cipta

Woodford, Paul G. (2004). Democracy and Music Education; Liberalism, Ethics, and the Politics of Practice. Bloomington, Indianapolis: Indiana University Press

Zamroni. (2011). Pendidikan Demokrasi pada Masyarakat Multikultural. Yogyakarta: Gavin Kalam Utama 